\title{
Start Date Time Of Dose Interval
}

National Cancer Institute

\section{Source}

National Cancer Institute. Start Date Time Of Dose Interval. NCI Thesaurus. Code C90459.

The date and time of the beginning of a dosing interval. 